\title{
"Using managerial and market tools to measure the impact of acquisition operations on firm performance"
}

\begin{tabular}{|c|c|}
\hline AUTHORS & $\begin{array}{l}\text { Zakia Abdelmoneim (D https://orcid.org/0000-0002-0679-2390 } \\
\text { Mostafa Abdelrahman Fekry }\end{array}$ \\
\hline ARTICLE INFO & $\begin{array}{l}\text { Zakia Abdelmoneim and Mostafa Abdelrahman Fekry (2021). Using managerial } \\
\text { and market tools to measure the impact of acquisition operations on firm } \\
\text { performance. Investment Management and Financial Innovations, 18(1), 315- } \\
\text { 334. doi:10.21511/imfi.18(1).2021.26 }\end{array}$ \\
\hline DOI & http://dx.doi.org/10.21511/imfi.18(1).2021.26 \\
\hline RELEASED ON & Tuesday, 23 March 2021 \\
\hline RECEIVED ON & Wednesday, 27 January 2021 \\
\hline \multirow[t]{2}{*}{ ACCEPTED ON } & Friday, 12 March 2021 \\
\hline & $(\mathrm{cc}) \mathrm{EY}$ \\
\hline LICENSE & $\begin{array}{l}\text { This work is licensed under a Creative Commons Attribution } 4.0 \text { International } \\
\text { License }\end{array}$ \\
\hline JOURNAL & "Investment Management and Financial Innovations" \\
\hline ISSN PRINT & $1810-4967$ \\
\hline ISSN ONLINE & $1812-9358$ \\
\hline PUBLISHER & LLC "Consulting Publishing Company "Business Perspectives" \\
\hline FOUNDER & LLC "Consulting Publishing Company "Business Perspectives" \\
\hline & 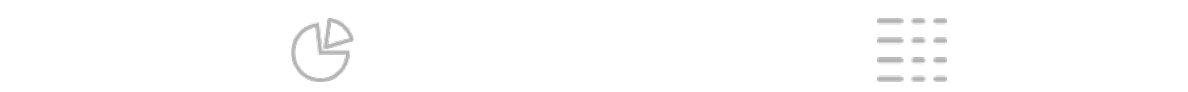 \\
\hline NUMBER OF REFERENCES & NUMBER OF FIGURES \\
\hline 41 & 12 \\
\hline
\end{tabular}

(c) The author(s) 2021. This publication is an open access article. 


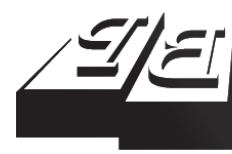

\section{BUSINESS PERSPECTIVES}

()

LLC "CPC "Business Perspectives" Hryhorii Skovoroda lane, 10, Sumy, 40022, Ukraine www.businessperspectives.org
Received on: $27^{\text {th }}$ of January, 2021 Accepted on: $12^{\text {th }}$ of March, 2021 Published on: $23^{\text {rd }}$ of March, 2021

(c) Zakia Abdelmoneim, Mostafa Abdelrahman Fekry, 2021

Zakia Abdelmoneim, Ph.D., Lecturer, Accounting Department, Faculty of Management Sciences, October University for Modern Sciences and Arts, Giza, Egypt. (Corresponding author)

Mostafa Abdelrahman Fekry, Ph.D. QNB, Cairo, Egypt.

\section{USING MANAGERIAL AND MARKET TOOLS TO MEASURE THE IMPACT OF ACQUISITION OPERATIONS ON FIRM PERFORMANCE}

\begin{abstract}
This paper aims to investigate and evaluate the effect of pre- and post-mergers and acquisitions (M\&A) on non-financial Egyptian firms' performance using a balanced scorecard (BSC), as well as to empirically investigate the impact of M\&A on shareholder wealth using cumulative abnormal returns (CAR). The paper is limited to non-financial firms listed on the Egyptian stock market (EGX) that have undergone acquisition operations during the time specified in the paper from 2003 to 2016. Four perspectives for the BSC are assessed before and after the acquisition operations to evaluate performance. The final sample for the BSC appraisal is 12 companies for 12 acquisition operations, while the sample for shareholders' wealth consists of 10 companies. The difference in the sample is that some companies became out-of-counter after the M\&A process. Cumulative differential analysis and graph observation show preferable values for post-acquisition operations versus pre-acquisition operations for the three non-financial perspectives, namely Customer satisfaction, Learning and growth, and Internal business process, and for two financial perspectives, namely Sales and Profitability. The results show preferable values for pre-acquisition operations for two financial perspectives: Liquidity and Market value. The T-test results failed to establish a relationship between M\&A and enhancing BSC perspectives. The results could not find any evidence to support the impact of pre-post M\&A on the shareholders' wealth. The relationship between BSC before and after M\&A and CAR is tested using a multiple regression model. The results show a significant relationship only between shareholder wealth and the Learning and growth perspective.
\end{abstract}

Keywords

acquisitions, balanced scorecard, cumulative abnormal return, shareholder wealth, Egyptian market

\section{JEL Classification E44, F36, L25}

\section{INTRODUCTION}

Recent rapid changes in the global business environment force shareholders and managers to make quick decisions to cope with the global technological and strategic changes. Mergers and Acquisitions (M\&A) is a vital way to restructure corporations and adjust their property and industrial structure to increase competitive advantage through improving overall performance. M\&A have become an inevitable choice for efficient resource allocation and enterprise development under the economic globalization (Chen, 2013). Companies started to combine together to avoid numerous risks evolved nowadays.

Traditionally, ratio analysis was a commonly used tool for firm' performance evaluation. Financial ratios measure the inside operation efficiency and profitability and ignore non-financial perspectives, systematic risk and long-term performance, focusing only on short-term performance. Accordingly, organizations started to use strategic managerial tools such as balanced scorecard (BSC) that take both financial and non-financial perspectives for more consistency and completeness, and to capture an overall view for the organization's value-creat- 
ing activities. BSC measures organizations' performance in four perspectives such as financial, customer, internal processes, and learning and growth (Chen, 2013; Kaplan \& Norton, 1992).

Abnormal return (AR) can be used to explain the returns on a given portfolio or security over a period of time that can be either positive or negative according to the security or portfolio performance over a specified period (Vazirani, 2012; Daadaa, 2016). To have a better evaluation of the degree of shareholder wealth before and after M\&A transaction market's reaction, cumulative abnormal returns (CAR) are considered a real economic indicator. CAR is an asset pricing model used to assess M\&A through testing market efficiency.

The main objective of this paper is to investigate and evaluate the effect of pre- and post-acquisitions on the performance of non-financial Egyptian firms using BSC, as well as to empirically investigate the impact of M\&A on shareholder wealth using CAR.

\section{LITERATURE REVIEW AND HYPOTHESES DEVELOPMENT}

M\&A are explained by a plenty of explanatory theories. In the efficient market, the stock prices respond to the company's announcement (Fama \& French, 1969), and thus, an action like M\&A would have a great impact on the company's value. In an efficient capital market, M\&A can led to either "wealth maximization" or "wealth minimization" through the finding of positive AR or negative AR around announcement days for the company acquirer (Chen et al., 2011). AR is useful in measuring the performance of securities or portfolio when compared to the overall market. AR helps in analyzing portfolio management performance based on risk-return basis to determine to what extent investors are compensated for the selected risk level (Rani et al., 2015).

From the human side, M\&A challenges and management problems can be explained by six theories (anxiety theory, social identity theory, acculturation theory, role conflict theory, job characteristics theory, and organizational justice theory), according to Seo and Hill (2005) who integrated those theories into one conceptual framework to explain behavioral and psychological effects for M\&A. Anxiety theory is concerned with employees' uncertainty and the impact of the M\&A decision on their careers. Social identity theory describes how employees' distinctive characteristics and attributes affect the M\&A adoption. Acculturation theory is concerned with the differ- ences in the cultures emerged from combination between different companies. Both role conflict and ambiguity job characteristic theories define the M\&A post actions regarding the role of expectation ambiguity and the reflection in job characteristics and work environments respectively. Organizational justice theory also describes the fairness of employees' treatment after M\&A.

In last four decades, numerous studies have been directed towards M\&A. Several studies have been proposed and studied the economic impact of M\&A on both performance evaluation and shareholder wealth. Most researchers have examined a critical question regarding whether the merging or acquiring company achieves the expected results or not. Different measures have been postulated for analyzing M\&A success both in the short and long term.

Among the studies examining the impact of M\&A on the firms' performance in developing countries is Lois et al. (2021) who used the profitability ratios to study the impact of M\&A on 50 post-mergers' performance to compare pre- and post-merger firm profitability around M\&A announcements of Greek listed firms in the short and long run. They found no improvement in the short-run performance and decrease in the long-run performance during the financial crisis. They could not find an impact for the method of payment, target's production line, or the internationalization of M\&A. In the same line, Grigorieva and Petrunina (2015) examined the performance of $80 \mathrm{M} \& \mathrm{~A}$ operations in emerging capital markets based on the economic profit model, and they found a declining value post-M\&A for combining firms. 
In contrast, these three studies concluded that the acquiring firms' overall performance had improved in the post-merger years (Rahman et al., 2021; Abdel-Azim et al., 2019; Duppati \& Rao, 2015). Rahman et al. (2021) studied the willingness of 34 emerging country firms to engage in cross-border M\&A through acquiring firms from developed countries for market penetration purposes. Abdel-Azim et al. (2019) examined the impact of domestic M\&As on firm performance to determine M\&As success and failure factors (i.e., weight efficiency, difference in efficiency, return on assets and return on equity) in 24 acquisition operations in EGX. Both Rahman et al. (2021) and Abdel-Azim et al. (2019) used two-stage analysis, data envelopment analysis (DEA) and Tobit regression. Duppati and Rao (2015) compared the long-term performance of 30 Indian firms with prior findings from the USA.

Deng and Yang (2015) compared cross-border M\&A with emerging market firms in the nine highest ranked emerging economies such as Brazil, India, Mexico, Indonesia, China, Russia, Thailand, South Africa, and Turkey. They concluded that the predictive power of the M\&A was affected by the government and the environmental factors.

BSC model is still under study for many researchers for strategic management evaluation. Among the researchers examining the impact of M\&A on performance using BSC is Kaplan (2020) who declared in his latest article that BSC was a logic step for managers to implement before the M\&A operation to highlight the difficulties and communicate the new strategy to lower-level employees. Kaplan stated that implementing BSC after M\&A adds value to customers because the created BSC model for the new integrated company breaks down different cultures and strategies between the acquirer and target companies, which affects the success of the M\&A process.

Alasfour (2020) examined a case study to understand Management Accounting and Control Systems (MACS) such as BSC and Budget in an Islamic bank after it was acquired by a conventional bank in Kuwait. The results showed that the parent bank expertise in BSC had benefited the acquired bank through achieving the targeted financial and non-financial objectives. BSC helped the acquired bank to reduce the conflict in Shariah, market and social aspects before the M\&A operation.

Zhang (2019) used BSC to evaluate the performance of Wanda Group's acquisition of legendary film industry. He concluded that the merger was not successful through analyzing the four perspectives of the BSC model. Zhang declared that from the financial perspective, both solvency and profitability deteriorated after the merger, as well from the learning and growth perspective.

Hristov and Chirico (2016) discussed the use of BSC in measuring M\&A performance through a questionnaire for 83 experienced Italian managers in companies involved in M\&A operations. Their results showed conflicted opinions between respondents who were convinced with the idea of BSC implementation versus others who were not. The respondents agreed on the use of BSC in extraordinary and large operations only.

Of the studies that have historically displayed the impact of M\&A on shareholder wealth using economic measures is the Ghatak (2017) study, in which a short event window of 61 days was examined for a sample of 8 target companies, $8 \mathrm{com}$ bined companies and 52 acquiring companies in IT Industry during the period from 2006 to 2015 . The results showed that the shareholders of the acquiring company, target company and combined company achieved positive AR from the M\&A activity.

Tianqi (2016) analyzed seven different studies that examine the shareholders' wealth using CAPM model in the period from 1980 to 2002. The results showed that M\&A created shareholder wealth for the target bank, while the M\&A impact on the acquiring bank is insignificant.

Busra (2015) analyzed the causes of shareholder value creation in Turkey's market in 2013 for overall market that undergone acquisition operations. Busra used CAR to measure AR of shareholder value for acquiring companies. The results show that the acquirer company loses value in the short run and increases in the long run.

Cortes et al. (2015) analyzed the impact of M\&A on shareholders' wealth for both acquiring and 
acquired airline companies in Latin America during the period from 1996 to 2013 . The results showed that after the announcement of M\&A, the AR of some selling companies was statistically significant.

Diaw (2015) investigated the effect of the M\&A announcement on shareholder wealth in European banking industry from 1997 to 2008 for 97 European banks. The results showed that CAR created value for both acquirer and target shareholders for companies undergone M\&A.

Rani et al. (2015) examined the impact of prepost M\&A on stock returns for 305 Indian firms that have undergone M\&A during the period of January 2003 to December 2008 using 14 financial ratios and abnormal return. The results indicated that there was a positive AR for new acquiring companies.

Sachdeva et al. (2015) evaluated the impact of the M\&A announcement on the shareholder value creation for 85 Indian acquiring companies listed on Bombay Stock Exchange (BSE) from 1991 to 2010. They used both CAR and AR. The results showed that during the announcement period, there was significant positive shareholders' wealth for acquiring companies. While after the announcement period, there was a decline in shareholder wealth for acquiring companies. Based on the above results of the study, M\&A did not have significant impact on the shareholders' value.

Priyanka and Parvinder (2014) examined the effect of M\&A announcements on the stock prices using CAR for both target and acquirer 37 publicly companies in the Asia-Pacific region during the period from May 2013 to September 2013. The results indicated that CAR of the target companies was statistically significant, while that of the acquirer companies was not statistically significant.

Bashir et al. (2011) evaluated the impact of 45 Pakistani M\&A companies on shareholder wealth value using CAR over the period from 2004 to 2010. The results indicated that target companies achieved insignificant decrease in value, while acquirer companies achieved insignificant increase in value.
Rani et al. (2011) investigated AR to 57 domestic and foreign Indian pharmaceutical companies that undergone M\&A from 2001 to 2007. The results showed a positive significant relationship between AR, CAR and shareholder wealth of Indian pharmaceutical companies on their M\&A foreign target, while M\&A activities in domestic pharmaceutical industry did not create shareholder wealth.

Maditinos et al. (2009) examined the impact of post M\&A on the Greek shareholder market value and investigated the effect of M\&A on the performance of Ioniki-Laiki and Pisteos banks (the merged banks). The data consisted of 122 daily closing transactions covering the period from 4-1-99 to 30-6-99. The study used the market index model that showed the relationship between the return on the market, return on a stock, and CAPM. The results showed an increase in the acquirer's shareholder performance following M\&A.

Choi and Russell (2004) examined 171 construction companies using CAR. The results indicated that shareholders of acquiring companies achieved positive CAR compared to the other companies' transactions. The results showed that the acquiring companies had a positive impact on market returns.

Diaz et al. (2004) investigated the impact of M\&A on 1,629 banks in the European Union between financial and non-financial banks using CAR through panel data methodology from 1993 to 2000. The results indicated that M\&A was more significant for financial banks than for non-financial banks.

Frank and Sam (2004) examined the stock financial performance of 97 target companies and 111 acquirer companies in the UK construction sectors involved in M\&A from 1996 to 2001. The results indicated that UK construction companies that undergone M\&A create an increase in CAR and AR for shareholders for both target and acquirer companies. The results showed a positive shareholder wealth related to UK companies that undergone M\&A.

Tse and Soufani (2001) investigated the impact of both acquired and acquiring companies on share- 
holder wealth in two different merger activity eras from 1990 to 1996 using CAR for 124 UK M\&A transactions. The results showed that the returns for the acquiring companies at the first periods from 1990 to 1993 were negative, while the returns for the acquiring companies at the second periods from 1994 to 1996 were positive. The results also indicated that the shareholders' wealth for acquirer was negative, while it was positive for target companies.

According to the previously mentioned studies, the economic measures, including $\mathrm{AR}$, are used to calculate the abnormal rate of return around the M\&A announcements window, which reflects the shareholders' reactions and, accordingly, their wealth in return.

Some of the literature discussed the impact of applying the BSC on the shareholders' wealth as a connection between inside and outside dimensions. While Crabtree and DeBusk (2008) provided a strong evidence that BSC increased shareholder returns, both Christesen (2008) and Lusk et al. (2006) did not find supported results between them. Lusk et al. (2006) recommended measuring the performance by market measures such as Capital Asset Pricing Model (CAPM).

According to the previously discussed literature, the following hypotheses are developed to be tested:

$H_{1}: \quad$ There is a significant positive relationship between $M \mho A s$ and financial performance.

$\mathrm{H}_{2}$ : There is a significant positive relationship between MઐAs and customer satisfaction.

$H_{3}$ : There is a significant positive relationship between MßAs and learning and growth performance.

$H_{4}$ : There is a significant positive relationship between M\&As and internal business process performance.

$H_{5}$ : There is a significant positive relationship between M↔A and increased shareholder wealth.

\section{$H_{6}$ : There is a significant positive relationship between BSC perspectives and shareholder wealth.}

\section{METHOD}

The paper follows the deductive approach, which is composed of two parts: the first is a theoretical study and literature review used to examine the impact of M\&A on the performance and shareholder wealth in the Egyptian market. For the purpose of this paper, data was collected from relevant journal articles, books, and historical studies. These sources provided the background information required to identify gaps in literature and develop the collection of data. The second part is an empirical part, which consists of three sections. First, using BSC to evaluate the effect of pre- and post-acquisitions on non-financial Egyptian firms' performance; second, to empirically investigate the impact of M\&A on shareholders' wealth using CAR, and third, to test the relationship between BSC perspectives of pre-post M\&A and CAR 60 and 120 using a multiple regression model for acquiring companies.

The paper is limited to non-financial firms listed on the Egyptian stock market (EGX) that were involved in acquisition operations within the time period 2003 to 2016 . There were no merger operations in Egypt within the research period time. The firm population in Egypt involved in acquisition operations consists of 215 firms. The paper examines a year before and a year after M\&A. According to the data collected, there was no full acquisitions for Egyptian non-financial firms happened within the period 2017-2019, and the year 2020 is not taken because the annual reports for the year after i.e., 2021 are not issued yet.

All acquirer companies that did not follow the Egyptian Accounting Standards (EAS) No. 29 and that were not fully controllers are excluded from the paper sample, as well as all cross border and unlisted Egyptian companies. The number of listed firms in the EGX out of the acquisition population is 49 firms, including 7 banks, 7 financial firms, 8 firms with insufficient data, and 15 firms with the acquisition percentage less than $30 \%$. 
Balanced scorecard (BSC)'s final sample for the paper is 12 firms for 12 operations within the period from 2003 to 2016. Four perspectives (i.e., financial, customer satisfaction, learning and growth performance, and internal business process) are measured for the BSC before and after the acquisition decision by a year to compare the results of the decision to examine the firm performance before and after the acquisition operation. The financial perspective involves sales, liquidity, profitability, and market. The non-financial perspective includes customer satisfaction, learning and growth performance, and internal business process performance.

The sample for CAR model consists of 10 out of 13 companies under study, this difference in the sample is due to the difficulty of data access for some companies that became out-of-counter after the $M \& A$ process.

The four BSC perspectives and their variables and measures are illustrated in Table 1.

Table 1. Balanced scorecard perspectives and their measures

\begin{tabular}{|c|c|c|c|}
\hline Perspective & Variables & Measurement & Formula used \\
\hline \multirow{4}{*}{$\begin{array}{l}\text { Financial } \\
\text { perspective }\end{array}$} & Sales & $\begin{array}{l}\text { Return on } \\
\text { Sales }\end{array}$ & $\begin{array}{c}\text { Net income } \\
\text { before tax } \\
\text { divided by total } \\
\text { sales }\end{array}$ \\
\hline & Liquidity & $\begin{array}{l}\text { Working } \\
\text { Capital }\end{array}$ & $\begin{array}{l}\text { Current } \\
\text { assets divided } \\
\text { by Current } \\
\text { Liabilities }\end{array}$ \\
\hline & Profitability & $\begin{array}{c}\text { Return on } \\
\text { Assets: ROA }\end{array}$ & $\begin{array}{c}\text { Net income } \\
\text { before tax } \\
\text { divided by total } \\
\text { assets }\end{array}$ \\
\hline & Market value & Stock price & $\begin{array}{c}\text { Stock price at } \\
\text { year end }\end{array}$ \\
\hline \multirow{3}{*}{$\begin{array}{l}\text { Non- } \\
\text { financial } \\
\text { perspective }\end{array}$} & $\begin{array}{l}\text { Customer } \\
\text { satisfaction }\end{array}$ & Log sales & $\begin{array}{c}\text { Log of total sales } \\
\text { at year end }\end{array}$ \\
\hline & $\begin{array}{l}\text { Learning } \\
\text { and growth } \\
\text { performance }\end{array}$ & $\begin{array}{c}\text { Research and } \\
\text { development } \\
\text { (R\&D) } \\
\text { expenses }\end{array}$ & $\begin{array}{c}R \& D \text { expenses at } \\
\text { year end }\end{array}$ \\
\hline & $\begin{array}{l}\text { Internal } \\
\text { business } \\
\text { process } \\
\text { performance }\end{array}$ & $\begin{array}{c}\text { Efficiency: } \\
\text { asset turnover }\end{array}$ & $\begin{array}{c}\text { Total sales } \\
\text { divided by total } \\
\text { assets }\end{array}$ \\
\hline
\end{tabular}

To define each day's AR, the paper used Yermack (1997)'s modified model of Dodd and Warner (1983)'s event-study methodology as follows:

$$
A R_{i, t}=R_{i, t}-R_{i, t}^{\prime}=R_{i, t}-a_{i}^{\prime}-\beta_{i} R m_{i, t},
$$

where $A R_{i, t}$ is the abnormal return on a stock defined as a return for company $i$ and acquisition date $t, R_{i, t}$ is the actual return of the stock, $R_{i, t}^{\prime}$ is excepted return of the stock, $R m_{i, t}$ is the yield on Index 30 for EGX, $i$ - companies, $t$ - days, and $a_{i}^{\prime}$ and $\beta_{i}$ are market model parameters.

$$
\underset{t=\tau_{1}}{\tau_{2}}=\sum A R_{i, t},
$$

$C A R_{i}$ - cumulative abnormal returns: use daily $A R$ s over an event period, where the event window is the interval $\left(\tau_{1}, \tau_{2}\right)-120$ working days, i.e. 60 days before and 60 days after the date of the event (M\&A date), and 240 working days, i.e. 120 days before and 120 days after the date of the event (M\&A date). The exact date of M\&A is not disclosed in the Egyptian market and the only available source is for the month and the year of the operation. The data is collected from Egypt for Information Dissemination (EGID).

\section{RESULTS}

The BSC perspectives for each acquisition operation results for each company under study are summarized in Appendix A.

The results for Olympic Group show an extreme increase in post-M\&A in learning perspective, a slight increase in internal, market, and customer perspectives, and a decrease in sales perspective. The results for Orascom Telecom show an extreme increase in post M\&A in sales perspective, a slight increase in liquidity, profitability, market, and customer perspectives. The rest perspectives remained approximately unchanged. The results for Sharm Dream show a slight increase in profitability and learning perspectives, and a decrease in sales, liquidity, market, and customer perspectives, while the rest perspectives remained approximately unchanged. The results for Egyptian Tourism show an extreme increase in post M\&A in learning perspective, while the rest perspectives remained approximately unchanged.

The results for Orascom Development show an extreme decrease in post M\&A in learning perspective, a slight decrease in market perspective, and 
approximately no change in the rest perspectives. The results for Orascom Construction show an increase in learning perspective, a slight increase in sales, liquidity, market, and customer perspectives, and approximately no change in the rest perspectives. The results for Telecom Egypt show an increase in liquidity, customer, and internal perspectives and a decrease in profitability, market, and learning perspectives. The results for Suez Cement show an increase in learning perspective and a slight decrease in market perspective, while the rest perspectives remained approximately unchanged. The results for Oriental Weavers show a decrease in learning perspective, a slight decrease in market perspective, while the rest perspectives remained approximately unchanged.

The results for Alexandria Portland show an increase in sales, profitability, and learning perspectives and a decrease in liquidity and market perspectives. The results for Sperea Misr show an increase in both liquidity and customer perspectives and a decrease in profitability, market, learning and internal perspectives. The results for National Navigation show an increase in liquidity, market, and customer perspectives, and a decrease in learning and internal perspectives.
The results for the financial perspective are shown in Figure 1, compromising the four main financial variables: sales, liquidity, profitability, and market value. For more illustration see Appendix B.

Sales increased in 9 firms and decreased in 4 firms. Sales increased in Orascom Telecommunication by 8.689866 , in the Egyptian firm for tourism by 0.32672 , in Orascom Construction by 0.401534 , in Telecom Egypt by 0.000792411, in Suez Cement by 0.401899 , in Oriental weavers by 0.007545 , in Alexandria Portland by 0.34149 , and in Sperea Misr by 0.052092677 . Sales decreased in Olympic group by -0.8444 , in Sharm Dreams by- 0.33876 , in Orascom Development by-0.01692, and in National navigation by -0.000792411 .

Liquidity increased in 7 firms and decreased in 6 firms. Liquidity increased in Olympic group financial by 0.053275 , in Orascom Telecommunication by 0.620022 , in Orascom construction by 0.633414 , in Telecom Egypt by 0.074983 , in Sperea by 0.933339816 , and in National navigation by 0.759010307 . Liquidity decreased in Sharm dreams by -0.712725 , in Egyptian company for tourism by -3.654202 , in Orascom Development by -0.174247 , in Suez Cement by -0.585069 , in

Financial perspective of pre- and post-M\&A across the sample

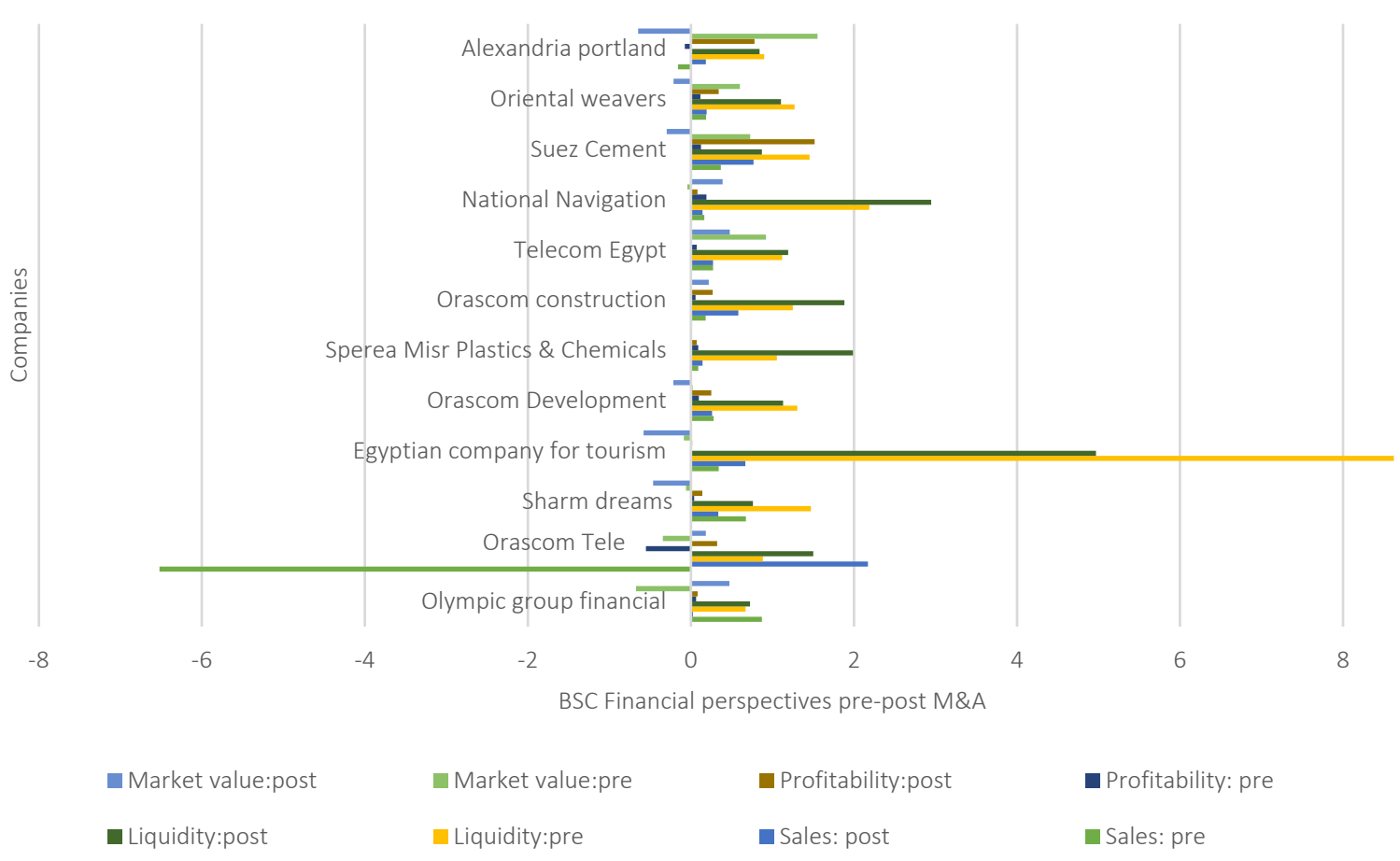

Figure 1. Pre- and post-M\&A financial perspective across the sample 
Oriental weavers by -0.167923 , and in Alexandria Portland by -0.056909 .

Profitability increased in 9 firms and decreased in 3 firms. It increased in Olympic group financial, Orascom Telecommunication, Sharm dreams, Egyptian company for tourism, Orascom Development, Orascom construction, Suez Cement, Oriental weavers, and Alexandria Portland by $0.01779513,0.87444717,0.10196728$, $0.00838808,0.15241631,0.21010857,1.42326288$, $1.39329691,0.22560683$, and 0.85566256 , respectively. Profitability decreased in 3 firms: Telecom Egypt (2006) by -0.0707014 , Sperea Misr by -0.018570104 , and National Navigation by -0.11004826 .

Market price increased in 4 firms and decreased in 8 firms. Market price increased in Olympic group, Orascom Telecommunication Orascom construction, and National Navigation by 1.146052364 , $0.528098592,0.225851391$, and 0.4314206, respectively. Market price decreased in the rest of the sampled firms. It decreased in Sharm dreams, Egyptian company for tourism, Orascom Development, Telecom Egypt, Suez Cement, Oriental weavers, and Alexandria Portland by $-0.403048528,-0.492087912,-0.236461538$, $-0.444109244,-1.023390477,-0.814284484$, and -2.201656911 , respectively.

The results for the non-financial perspective are illustrated in Figure 2, compromising the three main non-financial variables: customer, learning and growth, and internal business process. For more illustration see Appendix B.
Customer perspective increased in 9 firms and decreased in 3 firms. The log sales as an indicator for customer satisfaction has decreased in Sharm dreams, Egyptian company for tourism, and Oriental weavers by $-0.243322183,-0.053947221$, and -0.23634017 , respectively. Log sales increased in Olympic group by 1.290510762 , in Orascom Telecommunication by 0.689320026 , in Orascom Development by 0.158578356 , in Orascom construction by 0.336521096 , in Telecom Egypt by 0.056892279 , in Suez Cement by 0.168432361 , in Alexandria Portland by L.E 0.159428112, in Sperea Misr by 0.210344523 , and in National Navigation by 0.541468861 .

Learning perspective increased in 9 firms and decreased in 3 firms. R\&D expenses considered as an indicator for learning and growth performance decreased in 3 firms: Orascom Development by -1200.38 , Telecom Egypt by -0.3087 , and Oriental weavers by -173.372 . R\&D expenses increased in 9 firms: Olympic group financial, Sharm dreams, Egyptian company for tourism, Orascom construction, Suez Cement (2005), Alexandria Portland, Sperea Misr, and National Navigation by $11.674,0.06,409.022,9861.83,7.227,8.319,111.103$, $5.511,9861.832$, and 8.319 , respectively.

Internal business process perspective increased in 4 firms and decreased in 8 firms. The efficiency calculated by asset turnover as an indicator of internal business process performance has increased in Olympic group, Telecom Egypt, Alexandria Portland, and National Navigation by $1.142549,0.023754,0.085141$, and 7.777531139, respectively. Asset turnover decreased in Orascom

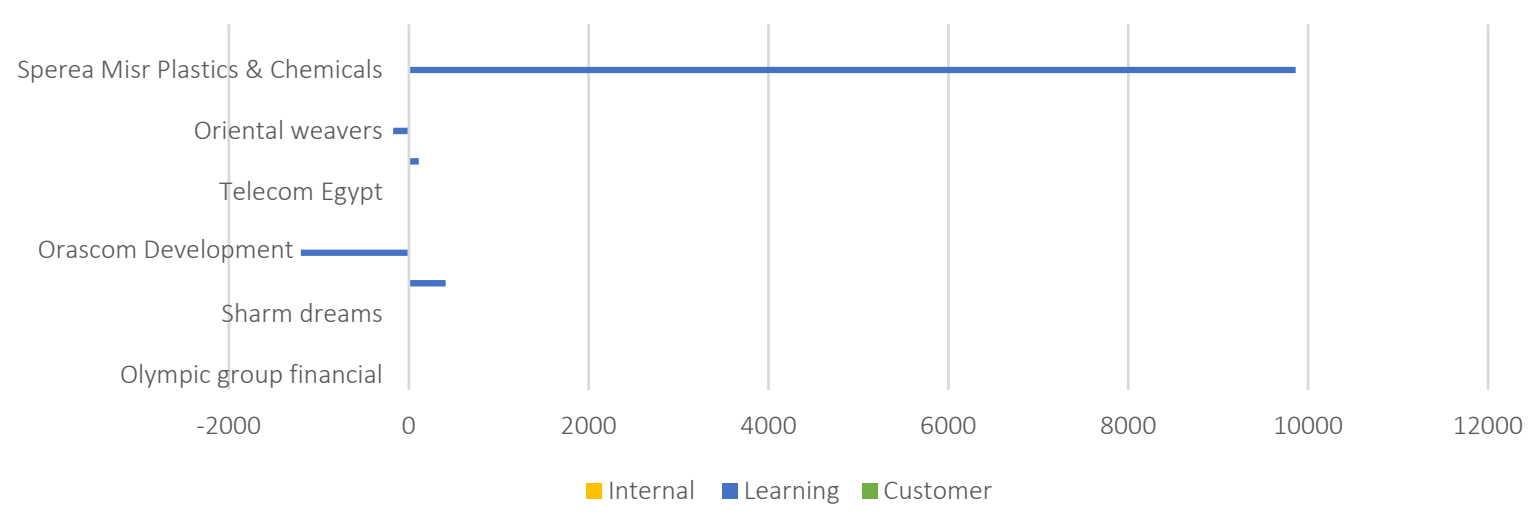

Figure 2. Non-financial perspective across the sample 
Telecommunication, Sharm dreams, Egyptian company for tourism, Orascom Development, Orascom construction, Suez Cement, Oriental weavers, and Sperea Misr by $-0.02623,-0.02551$, $-0.00202,-0.03622,-0.08828,-0.13153,-0.24366$, and -0.496968281 , respectively.

The second part of the BSC model is the t-test in Table 2 (see Appendix $C$ for statistical results). The results for the mean show preferable values for preM\&A than post-M\&A for the four financial perspectives: sales, liquidity, profitability, and market value at the insignificant level. It can be concluded that the mean shows preferable values at the insignificant level for post-M\&A than pre-M\&A for three non-financial perspectives: customer satisfaction, learning and growth performance, and internal business process performance.

The shareholders' wealth is investigated by 120 days using CAR analysis for the acquiring companies under study after excluding the companies that became out-of-counter after the M\&A process. Shareholder wealth is further investigated by 60 days using CAR analysis for the companies under study.

It was expected to find different results between CAR 60 days and CAR 120 days after finalizing M\&A for the following reasons; First regarding the narrow window around the M\&A event, analyzing 60 days before and after the event detected the acquirer shareholders' expectation for more gain that led to a rapid increase in the stock price for the acquiring company, which would mani- fest itself in an increase in AR. Second, measuring AR for the first period after announcement does not reflect the main financial problems associated with M\&A, i.e. for the 60-day period, the acquirer focuses more on non-financial factors such as marketing and technology to attract more customers and shareholders, but for the wider window the acquiring company starts to focus more on its financial problems. The narrow window would give more accurate and determined information because it excludes other factors affecting the event.

From Table 3 it can be concluded that differential CAR 120 days for the non-financial sector involves three companies with positive differential CAR, which are Olympic Group, Sharm Dreams for Hotels and Suez cement, while in CAR 60 days, only Telecom Egypt has a positive CAR differential.

For further investigation, the $t$-test is used to compare between post-CAR 60 days and pre-CAR 60 days, as well as between post-CAR 120 days and pre-CAR 120 days for acquiring companies. Table 4 shows that post-CAR 60 days are higher than pre-CAR 60 days and that pre-CAR 120 days is higher than post-CAR 120 days. These results are insignificant.

The relationship between BSC pre-post M\&A and CAR 60 and 120 is statistically tested by a multiple regression models for the acquiring companies. Appendices D and E illustrate a comprehensive table, including data used for BSC and CAR. The statistical results shown in Appendices F and

Table 2. T-test analysis to differentiate between pre- and post-M\&A results for the BSC model

\begin{tabular}{|c|c|c|c|c|c|c|c|}
\hline No. & Variables & Period & $\mathbf{N}$ & Mean & St. deviation & t-test & $\begin{array}{l}\text { Significance } \\
\text { level }\end{array}$ \\
\hline \multirow{2}{*}{1} & \multirow{2}{*}{$\begin{array}{l}\text { Sales } \\
\text { Return on sales }\end{array}$} & Pre-M\&A & 12 & 4.33652 & 16.74025 & \multirow{2}{*}{0.8130} & \multirow{2}{*}{.432} \\
\hline & & Post-M\&A & 12 & .7811049 & 1.187304 & & \\
\hline \multirow{2}{*}{2} & \multirow{2}{*}{$\begin{array}{l}\text { Liquidity } \\
\text { Working capital }\end{array}$} & Pre-M\&A & 12 & 2.111261 & 2.472037 & \multirow{2}{*}{1.7087} & \multirow{2}{*}{.113} \\
\hline & & Post-M\&A & 12 & 1.340184 & 1.179421 & & \\
\hline \multirow{2}{*}{3} & \multirow{2}{*}{$\begin{array}{l}\text { Profitability } \\
\text { Return on assets: ROA }\end{array}$} & Pre-M\&A & 12 & .5992443 & 2.254219 & \multirow{2}{*}{0.2696} & \multirow{2}{*}{.792} \\
\hline & & Post-M\&A & 12 & .4238291 & .5203023 & & \\
\hline \multirow{2}{*}{4} & \multirow{2}{*}{$\begin{array}{l}\text { Market value } \\
\text { Stock price }\end{array}$} & Pre-M\&A & 12 & .6484089 & 1.137638 & \multirow{2}{*}{2.0244} & \multirow{2}{*}{.066} \\
\hline & & Post-M\&A & 12 & -.0167042 & .4335107 & & \\
\hline \multirow{2}{*}{5} & \multirow{2}{*}{$\begin{array}{l}\text { Customer satisfaction } \\
\text { Total sales }\end{array}$} & Pre-M\&A & 12 & 2.343781 & .7101986 & \multirow{2}{*}{-1.2426} & \multirow{2}{*}{.238} \\
\hline & & Post-M\&A & 12 & 2.494749 & .7907252 & & \\
\hline \multirow{2}{*}{6} & \multirow{2}{*}{$\begin{array}{l}\text { Learning and growth performance } \\
R \& D \text { expenses }\end{array}$} & Pre-M\&A & 12 & 138.9807 & 380.1726 & \multirow{2}{*}{-0.9032} & \multirow{2}{*}{.384} \\
\hline & & Post-M\&A & 12 & 834.8566 & 2721.305 & & \\
\hline 7 & $\begin{array}{l}\text { Internal business process performance } \\
\text { Efficiency: asset turnover }\end{array}$ & Pre-M\&A & 12 & .3222482 & .381791 & -0.4176 & .684 \\
\hline
\end{tabular}


Table 3. Differential analysis between CAR 120 days and CAR 60 days for M\&A

\begin{tabular}{|c|c|c|c|c|c|c|}
\hline \multirow{2}{*}{ Non-fiinancial } & \multicolumn{3}{|c|}{ CAR 120} & \multicolumn{3}{|c|}{ CAR 60} \\
\hline & Pre-CAR & Post-CAR & Differential & Pre-CAR & Post-CAR & Differential \\
\hline Olympic Group & 15.39109 & 18.73101 & 3.33992092 & 0.090864 & -0.06637 & -0.157229867 \\
\hline Orascom Telecom Media \& Technology Holding & 0.054012 & -0.09289 & -0.146903002 & 0.043704 & -0.05822 & -0.101919847 \\
\hline Sharm Dreams Holding for Tourism \& Hotels & -0.09923 & 0.447326 & 0.546554121 & 0.10961 & -0.08791 & -0.197516259 \\
\hline Egyptian Company for Tourism \& Hotels & 0.146841 & -0.11761 & -0.264450924 & 0.05605 & -0.10758 & -0.163629132 \\
\hline Orascom Construction Industries & 0.543247 & -0.90537 & -1.44861895 & 0.325233 & -0.35927 & -0.68450289 \\
\hline Telecom Egypt & 0.36692 & -0.41322 & -0.780136519 & -0.05942 & 0.003677 & 0.063100731 \\
\hline Suez Cement & -0.07908 & 0.120413 & 0.199495899 & 0.117355 & -0.11254 & -0.229897894 \\
\hline Oriental Weavers & -0.04089 & -0.19331 & -0.152418899 & 0.108598 & -0.16418 & -0.272775707 \\
\hline Sperea & 0.482336 & -0.44017 & -0.92250998 & 0.404552 & -0.45912 & -0.863676664 \\
\hline National Navigation & 0.343097 & -0.35123 & -0.694331991 & 0.152305 & -0.18672 & -0.339023246 \\
\hline
\end{tabular}

Table 4. T-test for comparison between pre- and post-CAR 120 days and pre- and post-CAR 60 days

\begin{tabular}{|c|c|c|c|c|c|c|c|c|c|}
\hline \multicolumn{10}{|c|}{ Paired sample test } \\
\hline \multicolumn{7}{|c|}{ Paired differences } & \multirow{3}{*}{$\mathbf{t}$} & \multirow{3}{*}{$d f$} & \multirow{3}{*}{$\begin{array}{c}\text { Sig. } \\
\text { (2-tailed) }\end{array}$} \\
\hline \multicolumn{7}{|c|}{ 95\% confidence interval of the difference } & & & \\
\hline & & Mean & $\begin{array}{c}\text { Std. } \\
\text { deviation }\end{array}$ & $\begin{array}{c}\text { Std. } \\
\text { error } \\
\text { mean }\end{array}$ & Lower & Upper & & & \\
\hline Pair 1 & CAR120_post-CAR120_pre & -.10390 & 1.17071 & .29268 & -.72772 & .51993 & -.355 & 15 & .728 \\
\hline Pair 2 & CAR60_post-CAR60_pre & .02824 & .56216 & .14054 & -.27131 & .32780 & .201 & 15 & .843 \\
\hline
\end{tabular}

$\mathrm{G}$ found a significant relationship between shareholders wealth and learning and growth perspective only. Stata 14.2 (Statistics Data Analysis 2015) is used to run data for the following multiple regression models:

CAR60_pre ${ }_{i, T}=\alpha_{0}+\beta_{1}$ Sales_Pre + $+\beta_{2}$ Liquid_pre $+\beta_{3}$ Profit_Pre+ $+\beta_{4}$ Market_Pre $+\beta_{5}$ Cust_pre + $+\beta_{6} L E A R N_{-}$pre $+\beta_{7} I N T E R N_{-}$Pre $+e$,

CAR60_post p $_{i, T}=\alpha_{0}+\beta_{1}$ Sales_Post +

$+\beta_{2}$ Liquid_post $+\beta_{3}$ Profit_Post +

$+\beta_{4}$ Market_Post $+\beta_{5}$ Cust_post +

$+\beta_{6}$ LEARN_post $+\beta_{7}$ INTERN_Post $+e$,

CAR $120_{-}$pre $_{i, T}=\alpha_{0}+\beta_{1}$ Sales_Pre +

$+\beta_{2}$ Liquid_pre $+\beta_{3}$ Profit_Pre+

$+\beta_{4}$ Market_Pre $+\beta_{5}$ Cust_pre +

$+\beta_{6}$ LEARN_pre $+\beta_{7}$ INTERN_Pre $+e$,
CAR120_post ${ }_{i, T}=\alpha_{0}+\beta_{1}$ Sales_Post +

$+\beta_{2}$ Liquid_post $+\beta_{3}$ Profit_Post +

$+\beta_{4}$ Market_Post $+\beta_{5}$ Cust_post +

$+\beta_{6} L E A R N_{-}$post $+\beta_{7}$ INTERN_Post $+e$,

where $C A R 60_{-}$pre $_{i, T}$, i.e. 60 working days (3) before the $\mathrm{M} \& \mathrm{~A}$ date, CAR60_post $t_{i, T}$ , i.e. 60 working days after the M\&A date, $C A R 120_{-}$pre $_{i, T}$, i.e. 120 working days before the date of M\&A, CAR $120_{-}$post $_{i, T}$, i.e. 120 working days after the date of M\&A, Sales_Pre, Liquid_pre, Profit_Pre, Market_Pre, Cust_pre, LEARN_pre, and INTERN_Pre represent the

(4) BSC perspectives: sales, liquidity, profitability, market value customer, learning and growth, and internal business process respectively a year before the M\&A, Sales_Post, Liquid_post, Profit Post, Market_Post, Cust_post, LEARN_post, and INTERN_Post represent the BSC perspectives: sales, liquidity, profitability, market value customer, learning and growth, and internal business process respectively a year after the M\&A, $i$ - companies, $t$ - Days, and $e$ - error. 


\section{DISCUSSION}

BSC model is still under study for many researchers for strategic management evaluation. Although it is clear that BSC is important in pre-M\&A strategy setting, there is still a debate about its role in post-M\&A value adding. The results from BSC model are classified into two parts; The first part relates to the graph observation and the cumulative differential analysis in Appendices A and B that show preferable values for post-acquisition operations than pre-acquisition operations for two financial perspectives related to customer reaction, namely sales and profitability, and show preferable values for pre-acquisition operations versus post-acquisition operations for two financial perspec- tives related to the shareholder reaction such as liquidity and market value. The results show preferable values for post-acquisition operations than pre-acquisition operations for three non-financial perspectives: customer satisfaction, learning and growth performance, and internal business process performance. The results partially accept $H_{1}$, and accept $H_{2}, H_{3}$ and $H_{4}$. BSC model $t$-test results reject $H_{1}$ and do not support $H_{2}, H_{3}$, and $H_{4}$.

Regarding the literature for wealth effects, the general conclusion indicates that takeovers generate ARs for the shareholders of target companies. There is still a strong debate among researchers about the acquiring company wealth gains that will benefit to enhance or destroy shareholder wealth. Regarding

Table 5. Summary for results and their relation to literature

\begin{tabular}{|c|c|c|c|c|c|c|}
\hline $\begin{array}{l}\text { The paper's } \\
\text { hypotheses }\end{array}$ & Method used & Expected sign & Results' sign & Result & $\begin{array}{c}\text { Proponents } \\
\text { from literature }\end{array}$ & $\begin{array}{c}\text { Opponents } \\
\text { from literature }\end{array}$ \\
\hline \multirow{2}{*}{$\begin{array}{l}H_{1}: \text { There is a } \\
\text { significant positive } \\
\text { relationship } \\
\text { between M\&As } \\
\text { and financial } \\
\text { performance }\end{array}$} & $\begin{array}{l}\text { Graph observation } \\
\text { and cumulative } \\
\text { differential } \\
\text { analysis } \\
\text { (Appendices A } \\
\text { and B) }\end{array}$ & \multirow{2}{*}{$\begin{array}{l}\text { + preferable } \\
\text { values for post- } \\
\text { acquisition } \\
\text { operations than } \\
\text { pre-acquisition } \\
\text { operations }\end{array}$} & $\begin{array}{c}\text { + for Sales and } \\
\text { profitability; } \\
\text { - for Liquidity and } \\
\text { market value }\end{array}$ & $\begin{array}{l}\text { Partially } \\
\text { accept } H_{1}\end{array}$ & \multirow{6}{*}{$\begin{array}{c}\text { Kaplan (2020), } \\
\text { Alasfour (2020), } \\
\text { Grigorieva \& } \\
\text { Petrunina (2015) }\end{array}$} & \multirow{6}{*}{$\begin{array}{l}\text { Rahman et al. } \\
\text { (2021), Abdel- } \\
\text { Azim et al. (2019), } \\
\text { Zhang (2019); } \\
\text { Hristov \& Chirico } \\
\text { (2016), Duppati \& } \\
\text { Rao (2015) }\end{array}$} \\
\hline & $\begin{array}{c}T \text {-test (Table } 3 \text { and } \\
\text { Appendix } C)\end{array}$ & & Insignificant N/A & Reject $H_{1}$ & & \\
\hline $\begin{array}{l}H_{2}: \text { There is a } \\
\text { significant positive } \\
\text { relationship } \\
\text { between M\&As } \\
\text { and customer } \\
\text { satisfaction }\end{array}$ & \multirow{3}{*}{$\begin{array}{l}\text { Graph observation } \\
\text { and cumulative } \\
\text { differential } \\
\text { analysis } \\
\text { (Appendices A } \\
\text { and B) }\end{array}$} & \multirow{4}{*}{$\begin{array}{c}+ \\
\text { preferable } \\
\text { values for post- } \\
\text { acquisition } \\
\text { operations than } \\
\text { pre-acquisition } \\
\text { operations for the } \\
3 \text { non-financial } \\
\text { perspectives }\end{array}$} & $\begin{array}{c}+ \\
\text { preferable values } \\
\text { for post-acquisition }\end{array}$ & \multirow{3}{*}{$\begin{array}{c}\text { Accept } H_{2}, \\
H_{3} \\
H_{4}\end{array}$} & & \\
\hline $\begin{array}{l}\mathrm{H}_{3}: \text { There is a } \\
\text { significant positive } \\
\text { relationship } \\
\text { between M\&As and } \\
\text { learning and growth } \\
\text { performance }\end{array}$ & & & $\begin{array}{l}\text { operations than } \\
\text { pre-acquisition } \\
\text { operations for the } \\
3 \text { non-financial } \\
\text { perspectives }\end{array}$ & & & \\
\hline \multirow{2}{*}{$\begin{array}{l}\mathrm{H}_{4} \text { : There is a } \\
\text { significant positive } \\
\text { relationship between } \\
\text { M\&As and internal } \\
\text { business process } \\
\text { performance }\end{array}$} & & & & & & \\
\hline & $\begin{array}{l}T \text {-test (Table } 3 \text { and } \\
\text { Appendix C) }\end{array}$ & & $\begin{array}{l}\text { Insignificant } \\
\text { N/A }\end{array}$ & $\begin{array}{c}\text { Reject } H_{2} \\
H_{3} \\
H_{4}\end{array}$ & & \\
\hline \multirow{2}{*}{$\begin{array}{l}H_{5}: \text { There is a } \\
\text { significant positive } \\
\text { relationship } \\
\text { between M\&A and } \\
\text { the increase in } \\
\text { shareholder wealth }\end{array}$} & $\begin{array}{c}\text { Differential } \\
\text { analysis (Table 2) }\end{array}$ & & & & \multirow{2}{*}{$\begin{array}{c}\text { Diaw (2015); } \\
\text { Rani et al. (2011); } \\
\text { Maditinos et al. } \\
\text { (2009); Choi \& } \\
\text { Russell (2004); } \\
\text { and Frank \& Sam } \\
\text { (2004) }\end{array}$} & \multirow[b]{2}{*}{$\begin{array}{l}\text { Sachdeva et al. } \\
\text { (2015), Eije \& } \\
\text { Wiegerinck (2010) }\end{array}$} \\
\hline & $\begin{array}{c}T \text {-test (Table } 4 \\
\text { and Appendices D } \\
\text { and } \mathrm{E} \text { ) }\end{array}$ & + & $\begin{array}{l}\text { Insignificant } \\
\text { N/A }\end{array}$ & Reject $H_{5}$ & & \\
\hline $\begin{array}{l}H_{6}: \text { There is a } \\
\text { significant positive } \\
\text { relationship } \\
\text { between BSC } \\
\text { perspectives and } \\
\text { shareholder wealth }\end{array}$ & $\begin{array}{l}\text { Multiple } \\
\text { regression model } \\
\text { (Appendices F } \\
\text { and } \mathrm{G} \text { ) }\end{array}$ & + & $\begin{array}{l}\text { Significant positive } \\
\text { relationship } \\
\text { between the } \\
\text { shareholder wealth } \\
\text { and the learning } \\
\text { and growth } \\
\text { perspective }\end{array}$ & $\begin{array}{c}\text { Partially } \\
\text { accept } H_{6}\end{array}$ & $\begin{array}{c}\text { Crabtree \& } \\
\text { DeBuskto (2008) }\end{array}$ & $\begin{array}{c}\text { Christesen (2008), } \\
\text { Lusk et al. (2006) }\end{array}$ \\
\hline
\end{tabular}


the CAR results, the differential analysis could not support $H_{5}$, which stated that "There is a significant positive relationship between M\&A and increased shareholder wealth". $H_{5}$ is rejected for both CAR 120 days and CAR 60 days for the acquiring companies, since the results are insignificant.

Under $t$-test analysis, which is used to compare between post-CAR 60 days and pre-CAR 60 days and between post-CAR 120 days and pre-CAR 120 days for the acquiring companies, $H_{5}$ is reject- ed for both CAR 120 days and CAR 60 days as the results are insignificant.

The multiple regression model used to test the relationship between BSC pre-post M\&A and CAR 60 and 120 proved that there was a significant relationship between shareholder wealth and the learning and growth perspective. The results do not find any evidence for the other perspectives; then $H_{6}$ is rejected. The summary for paper results and their connection to literature is illustrated in Table 5.

\section{CONCLUSION}

The results for the BSC model show that M\&A enhances the internal management, production and marketing processes through learning and internal business efficiency and, as a result, increases sales and profitability through customer satisfaction. In contrast, CAR results showed no enhancement in the acquiring value after the M\&A. The shareholder value declines due to the method used in the acquisition process, be it asset or stock acquisition. Liquidity is affected by the purchase cost or cash released for acquiring the target in case of asset acquisition. The market value measured by the stock price is sensitive to methods of payment for both the acquirer and target in the short run. The results show a significant positive relationship between shareholder wealth and learning and growth perspective. This enhances the idea that shareholders care about $\mathrm{R} \& \mathrm{D}$ and new technology that may result from $M \& A$.

It is recommended for future research to measure the value creation for both the acquirer and the target in the long run and take into account other external factors, add cross-border comparative studies, and use other managerial accounting tools to assess the M\&A performance, such as Theory of Constraints (TOC) and Economic Value Added (EVA).

\section{AUTHOR CONTRIBUTIONS}

Conceptualization: Zakia Abdelmoneim, Mostafa Abdelrahman Fekry.

Data curation: Zakia Abdelmoneim, Mostafa Abdelrahman Fekry.

Formal analysis: Zakia Abdelmoneim, Mostafa Abdelrahman Fekry.

Investigation: Zakia Abdelmoneim, Mostafa Abdelrahman Fekry.

Methodology: Zakia Abdelmoneim, Mostafa Abdelrahman Fekry.

Project administration: Zakia Abdelmoneim, Mostafa Abdelrahman Fekry.

Supervision: Zakia Abdelmoneim, Mostafa Abdelrahman Fekry.

Validation: Zakia Abdelmoneim, Mostafa Abdelrahman Fekry.

Visualization: Zakia Abdelmoneim, Mostafa Abdelrahman Fekry.

Writing - original draft: Zakia Abdelmoneim, Mostafa Abdelrahman Fekry.

Writing - review \& editing: Zakia Abdelmoneim, Mostafa Abdelrahman Fekry. 


\section{REFERENCES}

1. Abdel-Azim, M. H., Soliman, W. S., \& Fekry, M. A. (2019). The Application of Two-Stage Approach in Evaluating Domestic Mergers and Acquisitions Performance Efficiency in Egypt. International Journal of Accounting and Financial Reporting, 9(2), 247-272. https://doi. org/10.5296/ijafr.v9i2.14702

2. Alasfour, M. (2020). Post-Acquisition Management Accounting and Control Systems in an Islamic Bank: An Institutional Logics Perspective (Ph.D. thesis). University of Essex. Retrieved from ProQuest Digital Dissertations. Retrieved from http:// repository.essex.ac.uk/27731/

3. Bashir, A., Sajid, M., \& Sheikh, S. (2011). The Impact of Mergers and Acquisitions on Shareholders Wealth: Evidence from Pakistan, Middle-East Journal of Scientific Research, 8(1), 261-264. Retrieved from https://www.researchgate.net/ publication/268357977_The_Impact_of_Mergers_and_Acquisitions_on_Shareholders_Wealth_Evidence_from_Pakistan

4. Busra, F. (2015). The Effects of Acquisitions on Firm Value, Evidence from T+urkey, Doğuş Üniversitesi Dergisi, 16(1), 7990. Retrieved from https:// www.researchgate.net/publication/327705007_The_Effects_of_ Acquisitions_on_Firm_Value_Evidence_from_Turkey

5. Chen, J. (2013). An Empirical Analysis on Performance of M\&A of Chinese Internet Companies Based on Balanced Scorecard. Advances in Applied Economics and Finance, 4(1), 663-667. Retrieved from http:// goletty.uad.ac.id/download_article. php?article $=82395$

6. Chen, S., Chou, R., \& Lee, C. (2011). Bidders' strategic timing of acquisition announcements and the effects of payment method on target returns and competing bids. Journal of Banking \& Finance, 35(9), 2231-2244. https://doi.org/10.1016/j. jbankfin.2011.01.029

7. Choi, J., \& Russel, J. (2004).

Economic Gains Around Mergers and Acquisitions in the Construction Industry of the United
States of America. Journal of Civil Engineering, 3(2), 513-525. https:// doi.org/10.1139/104-004

8. Christesen, D. A. (2008). The Impact of Balanced Scorecard Usage on Organization Performance (Ph.D. thesis). The Faculty of The Graduate School of The University of Minnesota. ProQuest Dissertations Publishing, 3302302. Retrieved from https://search.proquest.com/ docview/304595608/fulltextPDF/6 C59C0D9ABD7434EPQ/1?accoun tid $=63189$.

9. Cortes, L., Garcia, J., \& Agudelo, D. (2015). Effects of Mergers and Acquisitions on Shareholder Wealth: Event Study for Latin American Airlines. Latin American Business Review, 16, 205-226. https://doi.org/ 10.1080/10978526.2015.1075238

10. Crabtree, A. D., \& DeBusk, G. K. (2008). The effects of adopting the Balanced Scorecard on shareholder returns. Advances in Accounting, Incorporating Advances in International Accounting, 24, 8-15. https://doi:10.1016/j. adiac.2008.05.016

11. Daadaa, W. (2016). Abnormal Return, Market Reaction around Rating Announcement in Tunisian stock market. International Journal of Economics and Finance, 8(7), 322-329. https://doi.org/10.5539/ijef. v8n7p322

12. Deng, P., \& Yang, M. (2015). CrossBorder Mergers and Acquisitions by Emerging Market Firms: A Comparative Investigation. International Business Review, 24(1), 157-172. http://dx.doi.org/10.1016/j. ibusrev.2014.07.005

13. Diaw, A. (2015). The effect of mergers and acquisitions on shareholder wealth: the case of European banks. First International Conference of Cost Action IS0902, Systemic Risks, Financial Crises, and Credit. Saint-Denis, France, 1-31. Retrieved from https://hal.archivesouvertes.fr/hal-01184673

14. Diaz, B., Olalla, M., \& Azofra, S. (2004), Bank acquisitions and performance: evidence from a panel of European credit entities. Journal of Economics and Business, 56(5),
377-404. https://doi.org/10.1016/j. jeconbus.2004.02.001

15. Dodd, P., \& Warner, B. (1983). On Corporate Governance: A Study of Proxy Contests. Journal of Financial Economics, 11(6), 401-438. https://doi.org/10.1016/0304405X(83)90018-1

16. Duppati, G., \& Rao, N. (2015). Cross-border mergers and acquisitions: Mature markets vs. emerging markets - with special reference to the USA and India. Cogent Business \& Management, 2(1), 1-11.http://dx.doi.org/10.1080 /23311975.2015.1088817.

17. Lusk, E. I., Halperin, M., \& Zhang, B. (2006). The Balanced Scorecard: Suggestions for Rebalancing. Problems and Perspectives in Management, 4(2), 100-114. Retrieved from https://businessperspectives.org/pdfproxy.php?item_ id:542

18. Eije, H., \& Wiegerinck, H. (2010). Shareholders' reactions to announcements of acquisitions of private firms: Do target and bidder markets make a difference? International Business Review, 19(3), 360-377. https://doi.org/10.1016/j. ibusrev.2010.02.002

19. Fama E., \& French, K. (1993). Common risk factors in the returns on stock and bonds. Journal of Financial Economics, 33(1), 3-5. https://doi.org/10.1016/0304405X(93)90023-5

20. Frank, T., \& Sam C. (2004) The Impact of Mergers and Acquisitions on Shareholder Wealth in the UK Construction Industry. Engineering, Construction and Architectural Management, 11(1), 65-73. https://doi. org/10.1108/09699980410512674

21. Grigorieva, S., \& Petrunina, T (2015). The performance of mergers and acquisitions in emerging capital markets: new angle. Journal of Management Control, 26, 377-403. https://doi.org/10.1007/s00187-0150219-9.

22. Ghatak, A. (2017). Shareholders' Wealth Creation in Mergers and Acquisitions in Indian IT 
Industry: A Fowler and Rorke Model. Journal of Commerce \& Management Thought, 8(1), 44-76. https://doi.org/10.5958/0976478X.2017.00003.9

23. Hristov, I., \& Chirico, A. (2016). The Possible Use of Balanced Scorecard in The Due Diligence Process For M\&A Transactions. The 2016 WEI International Academic Conference Proceedings. The West East Institute. Retrieved from https://www. westeastinstitute.com/wp-content/ uploads/2016/12/Ivo-Hristov.pdf

24. Kaplan, R., \& Norton, D. (1992). The balanced scorecard: Measures that drive performance. Harvard Business Review, 70(1), 7179. Retrieved from https://hbr. org/1992/01/the-balanced-scorecard-measures-that-drive-performance-2

25. Kaplan, R. (2020). Using the Balanced Scorecard for Successful Health Care M\&A Integration. NEJM Catalyst Innovations in Care Delivery. Retrieved from https:// catalyst.nejm.org/doi/full/10.1056/ CAT.20.0286

26. Lois, P., Pazarskis, M., Drogalas, G., \& Karagiorgos, A. (2021). On Mergers and Acquisitions in Greece - Before and After the Onslaught of the Economic Crisis. The Journal of Developing Areas, 55(2), 353364. https://doi.org/10.1353/ jda.2021.0049

27. Maditinos, D., Theriou, N., \& Demetriades, E. (2009). The Effect of Mergers and Acquisitions on the Performance of CompaniesThe Greek Case of Ioniki-Laiki Bank and Pisteos Bank. Journal of European Research Studies, XII(2), 111-130. Retrieved from https://www.researchgate.net/ publication/46542650_The_Effect_of_Mergers_and_Acquisitions_ on_the_Performance_of_Companies_-_The_Greek_Case_of_IonikiLaiki_Bank_and_Pisteos_Bank

28. Priyanka, S., \& Parvinder, A. (2014). M\&A Announcements and Their Effect on Return to Shareholders: An Event Study. Accounting and Finance Research, 3(2), 170190. https://doi.org/10.5430/afr. v3n2p170

29. Rahman, M., Lambkin, M., \& Shams, R. (2021). Cross-border mergers and acquisitions: Impact on marketing capability and firm Performance. Journal of General Management, 46(2), 129-143, Sage publications. http://doi. org/10.1177/0306307020934673

30. Rani, N., Yadav, S., \& Jain, P. (2011). Impact of Mergers and Acquisitions on Shareholders' Wealth in Short-Run: An Empirical Study of Indian Pharmaceutical Industry. International Journal of Global Business and Competitiveness, 6(1), 40-52. Retrieved from https://www.researchgate.net/ publication/255697506_Impact_ of_Mergers_and_Acquisitions_on_ Shareholders'_Wealth_in_ShortRun_An_Empirical_Study_of_Indian_Pharmaceutical_Industry

31. Rani, N., Yadav, S., \& Jain, P. (2015). Financial performance analysis of mergers and acquisitions: Evidence from India. International Journal of Commerce and Management, 25(14), 402-423. https://doi.org/10.1108/ IJCoMA-11-2012-0075

32. Reda, M. (2013). The effect of mergers and acquisitions on bank efficiency: evidence from bank consolidation in Egypt (Working Paper 770, pp. 1-24). Retrieved from http://erf.org.eg/wp-content/ uploads/2014/07/770.pdf

33. Sachdeva, T., Sinha, N., \& Kaushik, K. (2015). Impact of Merger and Acquisition Announcement on Shareholders' Wealth. Delhi Business Review, 16(2), 19-36. https://doi. org/10.1177/0256090915600842

34. Seo, M., \& Hill, N. (2005). Understanding the Human Side of Merger and Acquisition: An Integrative Framework. The Journal of Applied Behavioral Science, 41(4), 422-443. https://doi. org/10.1177/0021886305281902

35. Tianqi, L. (2016). A study on the Impact of Mergers \& Acquisitions on Shareholders' Wealth and Efficiency. SHS Web of Conferences, 25, 02013. Retrieved from http://creativecommons.org/licenses/by/4.0/

36. Tse, T., \& Soufani, K. (2001). Wealth Effect of Takeovers in Merger Activity Eras: Empirical Evidence from the UK. International
Journal of Economics Business, 8(6), 365-377. https://doi. org/10.1080/13571510110079829

37. Turshan, M. N., \& Abdel Karim, N. (2020). The Effect of Adopting Balanced Scorecard (BSC) as Strategic Planning Tool on Financial Performance of Banks Operating in Palestine. Asian Social Science, 16(1), 95-108. Retrieved from https://www.researchgate.net/ publication/338289778_The_Effect_of_Adopting_Balanced_Scorecard_BSC_as_Strategic_Planning Tool_on_Financial_Performance_ of_Banks_Operating_in_Palestine

38. Vazirani, N. (2012). Mergers and Acquisitions Performance Evaluation- A Literature Review. SIES Journal of Management, 8(2), 37-42. Retrieved from http://eds.b.ebscohost.com/eds/ pdfviewer/pdfviewer?vid=0\&s id=b735a7bc-050a-48bb-b7a3ff838bd93b5d\%40pdc-v-sessmgr02

39. Wang, D., \& Moini, H. (2012). Performance assessment of mergers and acquisitions: Evidence from Denmark. Research Journal of Finance and Accounting, 3(6), 1-15. Retrieved from http://www.g-casa. com/conferences/berlin/papers/ Wang.pdf

40. Yermack, D. (1997). Good Timing: CEO Stock Option Awards and Company News Announcements. Journal of Finance, 52(12), 448-476. https:// doi.org/10.1111/j.1540-6261.1997. tb04809.x

41. Zhang, B. (2019). Performance Evaluation of Enterprise M\&A Based on BSC: Taking Wanda M\&A Legendary Film as an Example. 2019 9th International Conference on Education, Management, and Computer (ICEMC 2019). Francis Academic Press, UK. Retrieved from https://webofproceedings. org/proceedings_series/ESSP/ ICEMC\%202019/ICEMC19020.pdf 


\section{APPENDIX A}

Table A1. Pre- and post-M\&A BSC perspectives

\begin{tabular}{|c|c|c|c|c|c|c|c|c|c|c|c|c|c|c|c|}
\hline \multirow{3}{*}{ No: } & \multirow{3}{*}{$\begin{array}{l}\text { Name of a } \\
\text { company } \\
\text { acquirer }\end{array}$} & \multicolumn{7}{|c|}{ Pre-M\&A } & \multicolumn{7}{|c|}{ Post- M\&A } \\
\hline & & \multicolumn{4}{|c|}{$\begin{array}{l}\frac{\pi}{\frac{\pi}{U}} \\
\frac{\pi}{\pi} \\
\stackrel{\frac{\pi}{4}}{4}\end{array}$} & \multirow{2}{*}{ 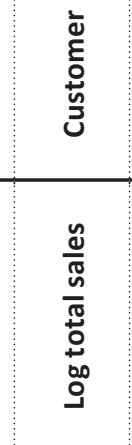 } & \multirow{2}{*}{ 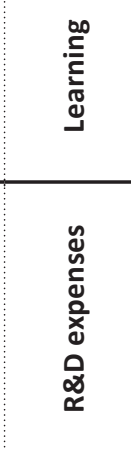 } & \multirow{2}{*}{ 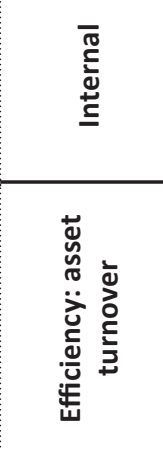 } & \multicolumn{4}{|c|}{$\begin{array}{l}\frac{\pi}{\frac{\pi}{U}} \\
\frac{\pi}{\pi} \\
\frac{5}{4}\end{array}$} & \multirow{2}{*}{ 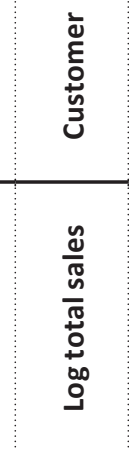 } & \multirow{2}{*}{ 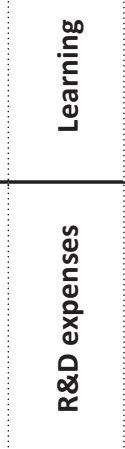 } & \multirow{2}{*}{ 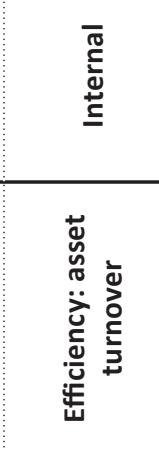 } \\
\hline & & 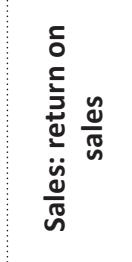 & 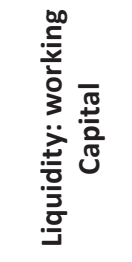 & 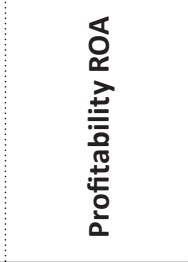 & 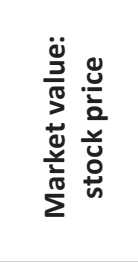 & & & & 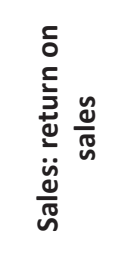 & 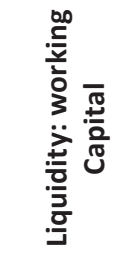 & 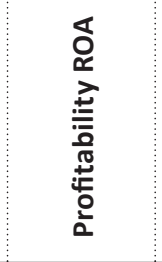 & 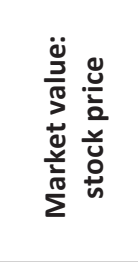 & & & \\
\hline 1 & $\begin{array}{l}\text { Olympic group } \\
\text { financial }\end{array}$ & 0.869384 & 0.670807 & 0.064169018 & -0.6741 & 2.029603 & 0 & 0.07380978 & 0.024988 & 0.724082 & 0.08196415 & 0.471954 & 3.320114 & 11.674 & 1.21635889 \\
\hline 2 & Orascom Tele & -6.51933 & 0.881218 & -0.55288244 & -0.345 & 2.055875 & 0 & 0.08480668 & 2.170539 & 1.50124 & 0.32156473 & 0.183099 & 2.745195 & 0 & 0.05857729 \\
\hline 3 & Sharm dreams & 0.67404 & 1.472278 & 0.039045271 & -0.06077 & 1.709448 & 0.146 & 0.05792724 & 0.335282 & 0.759554 & 0.14101255 & -0.46381 & 1.466126 & 0.206 & 0.03241583 \\
\hline 4 & $\begin{array}{l}\text { Egyptian } \\
\text { company for } \\
\text { tourism }\end{array}$ & 0.340513 & 8.624242 & 0.006385627 & -0.08791 & 1.504335 & 74.335 & 0.01875294 & 0.667234 & 4.97004 & 0.01477371 & -0.58 & 1.450388 & 483.357 & 0.016734 \\
\hline 5 & $\begin{array}{l}\text { Orascom } \\
\text { Development }\end{array}$ & 0.277313 & 1.305027 & 0.097233619 & 0.020462 & 2.609385 & 1388 & 0.35062781 & 0.260389 & 1.130781 & 0.24964993 & -0.216 & 2.767964 & 187.623 & 0.31440873 \\
\hline 6 & $\begin{array}{l}\text { Orascom } \\
\text { construction }\end{array}$ & 15537.15 & 6.504495 & 8.074131156 & 1.035647 & 3.047712 & 19.168 & 0.00051967 & 4.274642 & 1.654791 & 0.2790438 & 0.710723 & 2.702983 & 9881 & 0.01644824 \\
\hline 7 & Telecom Egypt & 0.271182 & 1.118466 & 0.071106095 & 0.921 & 0.922383 & 1.1397 & 0.26220843 & 0.271974 & 1.193449 & 0.00040469 & 0.476891 & 0.979275 & 0.831 & 0.28596281 \\
\hline 8 & Suez Cement & 0.366579 & 1.454832 & 0.123428882 & 0.726939 & 2.937663 & 0 & 0.33670443 & 0.768479 & 0.869763 & 1.5167258 & -0.29645 & 3.106096 & 111.103 & 0.20517782 \\
\hline 9 & Oriental weavers & 0.184935 & 1.272495 & 0.115915245 & 0.600882 & 3.204615 & 212.57 & 0.62678979 & 0.192479 & 1.104573 & 0.34152208 & -0.2134 & 2.968275 & 39.198 & 0.38313354 \\
\hline 10 & $\begin{array}{l}\text { Alexandria } \\
\text { portland }\end{array}$ & -0.15861 & 0.898328 & -0.07549362 & 1.553542 & 2.439846 & 13.685 & 0.47598425 & 0.182885 & 0.841419 & 0.78016894 & -0.64811 & 2.599274 & 19.196 & 0.56112495 \\
\hline 11 & $\begin{array}{l}\text { Sperea Misr } \\
\text { Plastics \& } \\
\text { Chemicals }\end{array}$ & 0.08978 & 1.054561 & 0.089509335 & 0 & 2.146503 & 8.93 & 0.99699027 & 0.141872 & 1.987901 & 0.07093923 & 0 & 2.356848 & 0.208 & 0.50002199 \\
\hline 12 & $\begin{array}{l}\text { National } \\
\text { Navigation }\end{array}$ & 0.162954 & 2.187147 & 0.189081831 & -0.0436 & 2.576811 & 1.582155 & 1.16034139 & 0.141194 & 2.946157 & 0.07903357 & 0.387821 & 2.34261 & 1.2355 & 0.55975331 \\
\hline
\end{tabular}




\section{W APPENDIX B}

Table B1. Differential analysis for post- and pre-M\&A BSC perspectives

\begin{tabular}{|c|c|c|c|c|c|c|c|}
\hline Company & $\begin{array}{c}\text { Sales: return on } \\
\text { sales }\end{array}$ & Liquidity: working Capial & Profitability ROA & $\begin{array}{l}\text { Market value: stock } \\
\text { price }\end{array}$ & Customer & Learning & Internal \\
\hline Olympic group financial & -0.844395674 & 0.053275206 & 0.017795133 & 1.146052364 & 1.29051076 & 11.674 & 1.142549113 \\
\hline Orascom Tele & 8.68986557 & 0.620021913 & 0.874447174 & 0.528098592 & 0.68932003 & 0 & -0.026229391 \\
\hline Sharm dreams & -0.338757893 & -0.712724567 & 0.101967282 & -0.40304853 & -0.24332218 & 0.06 & -0.025511409 \\
\hline Egyptian company for tourism & 0.326720399 & -3.654201758 & 0.008388081 & -0.49208791 & -0.05394722 & 409.022 & -0.002018939 \\
\hline Orascom Development & -0.016924127 & -0.174246844 & 0.152416308 & -0.23646154 & 0.15857836 & -1200.377 & -0.036219084 \\
\hline Orascom construction & 0.401533628 & 0.633413683 & 0.210108573 & 0.225851391 & 0.3365211 & 7.227 & -0.088282894 \\
\hline Telecom Egypt & 0.000792411 & 0.074983385 & -0.070701406 & -0.44410924 & 0.05689228 & -0.3087 & 0.02375438 \\
\hline Suez Cement & 0.40189928 & -0.585068805 & 1.393296915 & -1.02339048 & 0.16843236 & 111.103 & -0.131526615 \\
\hline Oriental weavers & 0.007544605 & -0.167922598 & 0.22560683 & -0.81428448 & -0.23634017 & -173.372 & -0.243656254 \\
\hline Alexandria portland & 0.341489831 & -0.056908756 & 0.855662562 & -2.20165691 & 0.15942811 & 5.511 & 0.085140701 \\
\hline Sperea Misr Plastics \& Chemicals & 0.052092677 & 0.933339816 & -0.018570104 & 0 & 0.21034452 & 9861.832 & -0.496968281 \\
\hline National Navigation & -0.021760045 & 0.759010307 & -0.11004826 & 0.4314206 & 0.54146886 & 8.319 & 7.777531139 \\
\hline Cumulative & 9.000100662 & -2.277029019 & 3.640369088 & -3.28361615 & 3.0778868 & 9040.6903 & 7.978562467 \\
\hline
\end{tabular}

\section{APPENDIX C}

Table C1. Statistical analysis for BSC analysis

\section{T-test}

\begin{tabular}{|c|c|c|c|c|c|}
\hline \multicolumn{6}{|c|}{ Paired Samples Statistics } \\
\hline & & Mean & $\mathbf{N}$ & Std. deviation & Std. error mean \\
\hline \multirow{2}{*}{ Pair 1} & Sales & 1195.4397 & 12 & 4309.14655 & 1195.14222 \\
\hline & Sales1 & .7811 & 12 & 1.18730 & .32930 \\
\hline \multirow{2}{*}{ Pair 2} & Liquidity & 2.1113 & 12 & 2.47204 & .68562 \\
\hline & Liquidity1 & 1.3402 & 12 & 1.17942 & .32711 \\
\hline \multirow{2}{*}{ Pair 3} & Profit & .6703 & 12 & 2.22500 & .61710 \\
\hline & Profit1 & .4238 & 12 & .52030 & .14431 \\
\hline \multirow{2}{*}{ Pair 4} & Market & 106.3231 & 12 & 156.13575 & 43.30427 \\
\hline & Market1 & 69.0400 & 12 & 89.03597 & 24.69413 \\
\hline \multirow{2}{*}{ Pair 5} & Customer & 439.4251 & 12 & 526.33655 & 145.97949 \\
\hline & Customer1 & 778.3529 & 12 & 771.65479 & 214.01853 \\
\hline \multirow{2}{*}{ Pair 6} & Learning & 138.9807 & 12 & 380.17261 & 105.44091 \\
\hline & Learning1 & 834.8566 & 12 & 2721.30473 & 754.75413 \\
\hline \multirow{2}{*}{ Pair 7} & Internal & .3222 & 12 & .38179 & .10589 \\
\hline & Internal1 & .3624 & 12 & .40402 & .11206 \\
\hline
\end{tabular}




\begin{tabular}{|c|c|c|c|c|}
\hline \multicolumn{5}{|c|}{ Paired sample correlations } \\
\hline & & $\mathbf{N}$ & Correlation & Sig. \\
\hline Pair 1 & Sales \& sales1 & 12 & .884 & .000 \\
\hline Pair 2 & Liquidity \& liquidity1 & 12 & .833 & .000 \\
\hline Pair 3 & Profit \& profit1 & 12 & $-.077-$ & .803 \\
\hline Pair 4 & Market \& market1 & 12 & .550 & .052 \\
\hline Pair 5 & Customer \& customer 1 & 12 & .547 & .053 \\
\hline Pair 6 & Learning \& learning1 & 12 & $-.081-$ & .793 \\
\hline Pair 7 & Internal \& internal1 & 12 & .612 & .026 \\
\hline
\end{tabular}

Paired sample test

\begin{tabular}{|c|c|c|c|c|c|c|c|c|c|}
\hline & & \multicolumn{5}{|c|}{ Paired differences } & \multirow{3}{*}{$\mathbf{t}$} & \multirow{3}{*}{$d f$} & \multirow{3}{*}{$\begin{array}{c}\text { Sig. } \\
\text { (2-tailed) }\end{array}$} \\
\hline & & \multirow{2}{*}{ Mean } & \multirow{2}{*}{ Std. deviation } & \multirow{2}{*}{$\begin{array}{l}\text { Std. error } \\
\text { mean }\end{array}$} & \multicolumn{2}{|c|}{$\mathbf{9 5 \%}$ confidence interval of difference } & & & \\
\hline & & & & & Lower & Upper & & & \\
\hline Pair 1 & Sales - sales1 & 1194.65857 & 4308.09692 & 1194.85110 & $-1408.69834-$ & 3798.01549 & 1.000 & 11 & .337 \\
\hline Pair 2 & Liquidity - liquidity 1 & .77108 & 1.62710 & .45128 & $-.21217-$ & 1.75432 & 1.709 & 11 & .113 \\
\hline Pair 3 & Profit - profit1 & .24643 & 2.32357 & .64444 & $-1.15769-$ & 1.65055 & .382 & 11 & .709 \\
\hline Pair 4 & Market - market1 & 37.28308 & 130.47228 & 36.18650 & $-41.56053-$ & 116.12669 & 1.030 & 11 & .323 \\
\hline Pair 5 & Customer - customer 1 & $-338.92785-$ & 654.03670 & 181.39714 & $-734.15827-$ & 56.30258 & $-1.868-$ & 11 & .086 \\
\hline Pair 6 & Learning - learning1 & $-695.87587-$ & 2778.06130 & 770.49557 & $-2374.64151-$ & 982.88977 & $-.903-$ & 11 & .384 \\
\hline Pair 7 & Internal - internal1 & $-.04014-$ & .34651 & .09611 & $-.24953-$ & .16926 & $-.418-$ & 11 & .684 \\
\hline
\end{tabular}

\section{APPENDIX D}

Table D1. Results for BSC and CAR pre-M\&A

\begin{tabular}{|c|c|c|c|c|c|c|c|c|c|}
\hline Company & $\begin{array}{c}\text { Sales: return } \\
\text { on sales }\end{array}$ & $\begin{array}{c}\text { Liquidity: working } \\
\text { Capital }\end{array}$ & $\begin{array}{c}\text { Profitability } \\
\text { ROA }\end{array}$ & $\begin{array}{c}\text { Market value: } \\
\text { stock price }\end{array}$ & $\begin{array}{c}\text { Log total } \\
\text { sales }\end{array}$ & $\begin{array}{c}R \& D \\
\text { expenses }\end{array}$ & $\begin{array}{c}\text { Efficiency: asset } \\
\text { turnover }\end{array}$ & $\begin{array}{c}\text { CAR } 60 \text { pre } \\
\text { M\&A }\end{array}$ & $\begin{array}{c}\text { CAR } 120 \text { pre } \\
\text { M\&A }\end{array}$ \\
\hline Olympic group financial & 0.869384 & 0.670807 & 0.064169 & -0.6741 & 2.029603 & 0 & 0.0738098 & 0.090864 & 9.6310162 \\
\hline Orascom Tele & -6.51933 & 0.881218 & -0.5528824 & -0.345 & 2.055875 & 0 & 0.0848067 & 0.043704 & -0.0309629 \\
\hline Sharm dreams & 0.67404 & 1.472278 & 0.0390453 & -0.06077 & 1.709448 & 0.146 & 0.0579272 & 0.10961 & -0.08022 \\
\hline $\begin{array}{l}\text { Egyptian company for } \\
\text { tourism }\end{array}$ & 0.340513 & 8.624242 & 0.0063856 & -0.08791 & 1.504335 & 74.335 & 0.0187529 & 0.05605 & -0.09447 \\
\hline Orascom Development & 0.277313 & 1.305027 & 0.0972336 & 0.020462 & 2.609385 & 1388 & 0.3506278 & 0.325233 & -0.4574181 \\
\hline Telecom Egypt & 0.271182 & 1.118466 & 0.0711061 & 0.921 & 0.922383 & 1.1397 & 0.2622084 & -0.05942 & -0.31694 \\
\hline Suez Cement & 0.366579 & 1.454832 & 0.1234289 & 0.726939 & 2.937663 & 0 & 0.3367044 & 0.117355 & -0.33439 \\
\hline Oriental weavers & 0.184935 & 1.272495 & 0.1159152 & 0.600882 & 3.204615 & 212.57 & 0.6267898 & 0.108598 & -0.11682 \\
\hline $\begin{array}{l}\text { Sperea Misr Plastics \& } \\
\text { Chemicals }\end{array}$ & 0.08978 & 1.054561 & 0.0895093 & 0 & 2.146503 & 8.93 & 0.9969903 & 0.404552 & -0.22841 \\
\hline National Navigation & 0.162954 & 2.187147 & 0.1890818 & -0.0436 & 2.576811 & 1.582155 & 1.1603414 & 0.152305 & -0.167438 \\
\hline
\end{tabular}




\section{$\underset{N}{W}$ APPENDIXE}

Table E1. Results for BSC and CAR post-M\&A

\begin{tabular}{|c|c|c|c|c|c|c|c|c|c|}
\hline Company & $\begin{array}{l}\text { Sales: return } \\
\text { on sales }\end{array}$ & $\begin{array}{c}\text { Liquidity: working } \\
\text { Capital }\end{array}$ & $\begin{array}{c}\text { Profitability } \\
\text { ROA }\end{array}$ & $\begin{array}{l}\text { Market value: } \\
\text { stock price }\end{array}$ & $\begin{array}{l}\text { Log total } \\
\text { sales }\end{array}$ & $\begin{array}{c}\text { R\&D } \\
\text { expenses }\end{array}$ & $\begin{array}{c}\text { Efficiency: asset } \\
\text { turnover }\end{array}$ & $\begin{array}{c}\text { CAR } 60 \text { post } \\
\text { M\&A }\end{array}$ & $\begin{array}{c}\text { CAR } 120 \text { post } \\
\text { M\&A }\end{array}$ \\
\hline Olympic group financial & 0.024988 & 0.724082 & 0.0819642 & 0.471954 & 3.320114 & 11.674 & 1.2163589 & -0.06637 & 18.73101 \\
\hline Orascom Tele & 2.170539 & 1.50124 & 0.3215647 & 0.183099 & 2.745195 & 0 & 0.0585773 & -0.05822 & -0.0928907 \\
\hline Sharm dreams & 0.3352821 & 0.759554 & 0.1410126 & -0.46381 & 1.466126 & 0.206 & 0.0324158 & -0.08791 & 0.447326 \\
\hline $\begin{array}{l}\text { Egyptian company for } \\
\text { tourism }\end{array}$ & 0.667234 & 4.97004 & 0.0147737 & -0.58 & 1.450388 & 483.357 & 0.016734 & -0.10758 & -0.11761 \\
\hline Orascom Development & 0.260389 & 1.130781 & 0.2496499 & -0.216 & 2.767964 & 187.623 & 0.3144087 & -0.35927 & -0.9053717 \\
\hline Telecom Egypt & 0.271974 & 1.193449 & 0.0004047 & 0.476891 & 0.979275 & 0.831 & 0.2859628 & 0.003677 & -0.41322 \\
\hline Suez Cement & 0.768479 & 0.869763 & 1.5167258 & -0.29645 & 3.106096 & 111.103 & 0.2051778 & -0.11254 & 0.120413 \\
\hline Oriental weavers & 0.192479 & 1.104573 & 0.3415221 & -0.2134 & 2.968275 & 39.198 & 0.3831335 & -0.16418 & -0.19331 \\
\hline $\begin{array}{l}\text { Sperea Misr Plastics \& } \\
\text { Chemicals }\end{array}$ & 0.141872 & 1.987901 & 0.0709392 & 0 & 2.356848 & 0.208 & 0.500022 & -0.45912 & -0.44017 \\
\hline National Navigation & 0.141194 & 2.946157 & 0.0790336 & 0.387821 & 2.34261 & 1.2355 & 0.5597533 & -0.18672 & -0.351235 \\
\hline
\end{tabular}




\section{APPENDIX F}

Table F1. Testing the relationship between BSC perspectives and CAR 60\&120 pre-M\&A

\begin{tabular}{|c|c|c|c|c|c|c|}
\hline Equation & Obs & & ISE & R-sq" & F & P \\
\hline CAR60preMA & 10 & .112 & .1127108 & .8461 & 1.571047 & 0.4428 \\
\hline \multirow[t]{2}{*}{ CAR120preMA } & 10 & \multicolumn{2}{|c|}{3.277514} & .7536 & .873915 & 0.6284 \\
\hline & Coef. & Std. Err. & t & $P>|t|$ & [95\% Conf. & Interval] \\
\hline \multicolumn{7}{|l|}{ CAR60preMA } \\
\hline salesPRE & .269718 & .1697992 & 1.59 & 0.253 & -.460869 & 1.000305 \\
\hline LiquidityPRE & -.0054581 & .017193 & -0.32 & 0.781 & -.0794336 & .0685174 \\
\hline ProfitabilityPRE & -3.100673 & 2.005728 & -1.55 & 0.262 & -11.73062 & 5.529276 \\
\hline MarketPRE & .0128412 & .1073988 & 0.12 & 0.916 & -.4492584 & .4749407 \\
\hline CUSTOMERPRE & .0763196 & .0776568 & 0.98 & 0.429 & -.2578107 & .4104499 \\
\hline LEARNPRE & .0001858 & .000098 & 1.90 & 0.198 & -.0002357 & .0006073 \\
\hline INTERNALPRE & .5476884 & .2612149 & 2.10 & 0.171 & -.5762286 & 1.671605 \\
\hline _cons & -.1059572 & .1694006 & -0.63 & 0.596 & -.8348291 & .6229147 \\
\hline \multicolumn{7}{|l|}{ CAR120preMA } \\
\hline salesPRE & -1.679926 & 4.937587 & -0.34 & 0.766 & -22.92465 & 19.56479 \\
\hline LiquidityPRE & -.5291517 & .4999545 & -1.06 & 0.401 & -2.680282 & 1.621979 \\
\hline ProfitabilityPRE & 28.98797 & 58.3245 & 0.50 & 0.668 & -221.9621 & 279.938 \\
\hline MarketPRE & -5.344431 & 3.123046 & -1.71 & 0.229 & -18.78181 & 8.09295 \\
\hline CUSTOMERPRE & -.016163 & 2.25818 & -0.01 & 0.995 & -9.732329 & 9.700003 \\
\hline LEARNPRE & -.002664 & .0028488 & -0.94 & 0.448 & -.0149213 & .0095933 \\
\hline INTERNALPRE & -6.703738 & 7.595862 & -0.88 & 0.471 & -39.38609 & 25.97862 \\
\hline _cons & 4.295504 & 4.925995 & 0.87 & 0.475 & -16.89934 & 25.49035 \\
\hline
\end{tabular}




\section{APPENDIX G}

Table G1. Testing the relationship between BSC perspectives and CAR $60 \& 120$ post-M\&A

\begin{tabular}{lcrrrrr} 
Equation & Obs & Parms & RMSE & "R-sq" & F & $P$ \\
\hline CAR120postMA & 10 & 8 & 2.2004 & 0.9701 & 9.281623 & 0.1007 \\
CAR60postMA & 10 & 8 & .2138302 & 0.5084 & .2955002 & 0.9063
\end{tabular}

\begin{tabular}{|c|c|c|c|c|c|c|}
\hline & Coef. & Std. Err. & t & $P>|t|$ & [95\% Conf. & Interval] \\
\hline \multicolumn{7}{|l|}{ CAR120postMA } \\
\hline salesPOST & 8.400483 & 2.222387 & 3.78 & 0.063 & -1.161676 & 17.96264 \\
\hline LiquidityPosT & -1.727498 & .9795686 & -1.76 & 0.220 & -5.942242 & 2.487246 \\
\hline ProfitabilityPosT & 1.426259 & 2.468047 & 0.58 & 0.622 & -9.19289 & 12.04541 \\
\hline MarketPOST & -10.95669 & 4.471878 & -2.45 & 0.134 & -30.19763 & 8.284245 \\
\hline CUSTOMERPOST & -6.115773 & 2.108401 & -2.90 & 0.101 & -15.18749 & 2.955943 \\
\hline LEARNPOST & .0085063 & .0098041 & 0.87 & 0.477 & -.0336774 & .05069 \\
\hline INTERNALPOST & 36.24273 & 6.716521 & 5.40 & 0.033 & 7.343869 & 65.14159 \\
\hline _cons & .5085268 & 3.167594 & 0.16 & 0.887 & -13.12053 & 14.13758 \\
\hline \multicolumn{7}{|l|}{ CAR60postMA } \\
\hline salesPoST & .2017846 & .2159669 & 0.93 & 0.449 & -.7274459 & 1.131015 \\
\hline LiquidityPOST & -.039999 & .0951924 & -0.42 & 0.715 & -.4495789 & .3695809 \\
\hline ProfitabilityPOST & .1565418 & .2398396 & 0.65 & 0.581 & -.8754048 & 1.188488 \\
\hline MarketPOST & -.0320655 & .4345676 & -0.07 & 0.948 & -1.901859 & 1.837728 \\
\hline CUSTOMERPOST & -.2168369 & .2048899 & -1.06 & 0.401 & -1.098407 & .6647333 \\
\hline LEARNPOST & .000258 & .0009527 & 0.27 & 0.812 & -.0038413 & .0043573 \\
\hline INTERNALPOST & .4503102 & .6526974 & 0.69 & 0.562 & -2.35802 & 3.25864 \\
\hline _cons & .0908398 & .3078201 & 0.30 & 0.796 & -1.233603 & 1.415283 \\
\hline
\end{tabular}

